\title{
"MANIAK" MEDIA SOSIAL DAN GAME PADA ANAK USIA DASAR (STUDI PADA SISWA MADRASAH IBTIDAIYAH YOGYAKARTA)
}

\author{
Ahmad Shofiyuddin Ichsan \\ Program Studi Pendidikan Guru Madrasah Ibtidaiyah, Fakultas Tarbiyah \\ Institut Ilmu Al Qur'an An Nur Yogyakarta \\ ahmad.shofiyuddin.ichsan@gmail.com
}

\begin{abstract}
Abstrak
Penelitian ini bertujuan untuk mengetahui efek penggunaan media sosial (WhatsApp, Instagram, dan Facebook) dan game di kalangan anak-anak Madrasah Ibtidaiyah di Yogyakarta, peran orangtua dan pemerintah dalam memberikan pemahaman penggunaan media sosial dan game, dan analisa penanggulangan media sosial dan game dalam perspektif interdisipliner. Objek dalam penelitian ini adalah dua Madrasah Ibtidaiyah di Yogyakarta, yakni di MI Ma'arif Sananul Ula Piyungan Bantul, dan MI Negeri 1 Bantul. Hasil penelitian mengungkapkan bahwa ada empat hal positif dan negatif yang didapatkan dari penggunaan media sosial di kalangan anak usia Sekolah Dasar. Sedangkan dalam pendekatan interdisipliner, terdapat tiga pendekatan, di antaranya: 1). Pendekatan Normatif (agama), 2). Pendekatan Psikologi Media, dan 3). Pendekatan Ekologi Media.
\end{abstract}

Kata Kunci: Media Sosial, Game, Siswa Madrasah Ibtidaiyah

\begin{abstract}
The aim of this study is to know the effect of the usage of social media (Whats App, Instagram, and Facebook) and games in MI students in Yogyakarta, the role of parents and goverment in giving understanding about the use of social media and games, and analyse the prevention of social media in interdisipliner perspective. Objects of this study are MI in Yogyakarta, they are MI Ma'arif Sananul Ula Piyungan Bantul and MI Negeri 1 Bantul. The result of this study show that there are four positive and negative effect from the use of social media in MI students. While in interdisipliner approach, there are 3 approaches, such as: 1) Nomative Approach (religion), 2) Media Psychological Approach, 3) Media Ecologycal Approach.
\end{abstract}

Keywords: Social Media, Games, Students, Madrasah Ibtidaiyah (MI)

\section{A. PENDAhuluan}

Setidaknya dalam kurun waktu 10 tahun terakhir (di tengah era digitalgadget saat ini), hubungan interaksi sosial di kalangan masyarakat sangat meningkat tajam. Hal ini salah satunya dikarenakan adanya kebutuhan komunikasi manusia dengan yang lain juga meningkat. Interaksi sosial di sini tentu 
berhubungan dengan dunia sosial satu orang dengan yang lain, juga antara kelompok satu dengan yang lain. Dalam artian, jika dalam dunia sosial seseorang bertatap muka dengan yang lain, hal tersebut sudah bagian dari interaksi sosial.

Dipahami bahwa setiap aktivitas yang dilakukan antara satu atau sekelompok dengan yang lain maka itu termasuk bagian dalam interaksi sosial. Meskipun seseorang bertemu secara langsung tidak saling berbicara satu dengan yang lain, interaksi sosial pun telah terjadi. Hal ini karena di antara mereka menyadari adanya pihak lain yang bisa merubah baik dalam perasaan orang tersebut maupun syaraf orang yang ditemuinya. Hal ini mungkin disebabkan adanya (misalnya) minyak wangi yang dipakai, suara orang berjalan, dan seterusnya yang semuanya itu menimbulkan kesan di benak seseorang, yang kemudian mampu menentukan tindakan yang akan dilakukannya. ${ }^{1}$

Meningkatnya manusia dalam berinteraksi secara sosial dengan manusia lain tentu dipengaruhi beberapa faktor, salah satunya massalnya teknologi informasi merambah ke sendi-sendi kehidupan masyarakat, dari masyarakat perkotaan sampai ke masyarakat pedesaan, dan dari masyarakat 'modernnonreligius' sampai pada masyarakat 'tradisional-religius'. Dengan berkembangnya teknologi informasi ini, tentu terjadi perubahan dari masyarakat lokal mengarah ke masyarakat global. Dalam artian, adanya teknologi informasi (yang tidak terbatas waktu dan ruang ini) telah memberikan kemudahan bagi manusia untuk melakukan interaksi sosial dengan manusia lainnya. Media sosial memicu banyak perubahan manusia dalam bersosialisasi. ${ }^{2}$ Perubahan masyarakat lokal ke global menjadikan manusia memiliki "dunia baru” yang dipersepsikan banyak orang sebagai peradaban modern, di mana manusia tidak lagi hanya berinteraksi di dunia nyata, tetapi sekaligus mereka juga mampu berinteraksi di dunia maya.

\footnotetext{
${ }^{1}$ Soerjono Soekanto, Sosiologi: Suatu Pengantar, Jakarta: PT. Raja Grafindo Persada, 2009.

${ }^{2}$ Sari Melati, Mahasiswa Pengguna Media Sosial (Studi Tentang Fungsi Media Sosial Bagi Mahasiswa Fisip UR), Jurnal JOM Fisip Vol. 2 Nomor 2 Oktober 2015, hlm. 2-3
} 
Dalam konteks interaksi sosial di era modern, Anthony Giddens mencoba menguraikan bahwa hubungan antara ruang dan waktu akan terputus dan kemudian ruang tersebut sedikit demi sedikit akan terpisah dari tempat semula. ${ }^{3}$ Pernyataan Giddens tersebut berimplikasi bahwa seorang manusia dapat menciptakan interaksi baru tanpa harus bertemu secara fisik dalam dunia nyata. Hal ini salah satunya dengan cara penggunaan teknologi, atau lebih dispesifikkan melalui internet (social networking). Semakin berkembangnya penggunaan teknologi informasi dan meningkatnya kebutuhan untuk berinteraksi menjadikan social networking ini menjadi sesuatu yang tidak bisa dibendung kembali. Social media (media sosial) menjadi bagian penting teknologi informasi yang memberikan ruang dan waktu interaksi tak terbatas bagi semua kalangan, sampai kalangan anak-anak sekalipun.

Media sosial sendiri, di zaman modern saat ini, telah memperlihatkan bagaimana ia mampu memicu banyak perubahan manusia dalam bersosialisasi. Media sosial tak hanya berguna sebagai media interaksi semata, tetapi ia telah menjadi sumber informasi yang sangat cepat melebihi media-media lain, seperti koran, majalah, radio maupun televisi. Maka tidak mengherankan jika informasi apapun (baik itu positif maupun negatif) lebih cepat masuk di media sosial daripada di media-media lain.

Tidak hanya media sosial, fenomena penggunaan game di kalangan anak pun pada beberapa tahun terakhir ini sudah semakin 'menggila'. Kita bisa menyaksikan di tahun 2016 Unity Technologies membuat penelitian dan merilis laporan terbarunya tentang perkembangan pasar game di dunia, khususnya fitur aplikasi game di handphone. Di dalam salah satu laporannya, penggunaan game di Indonesia saat ini terus mengalami peningkatan yang sangat signifikan, bahkan penggunaan game di negara kita sangat tinggi hingga mencapai tiga kali lipat

\footnotetext{
${ }^{3}$ Lihat Henry Priyono, Anthony Giddens Suatu Pengantar, Jakarta: Perpustakaan Populer Gramedia, 2003.
} 
dibandingkan tiga negara besar, salah satunya Amerika Serikat. ${ }^{4}$ Hal ini setidaknya terbukti hasil penelitian Dony Canggah Guno yang menyebutkan bahwa rata-rata anak bermain game berdurasi mulai 20 sampai 23 jam dalam seminggu. ${ }^{5}$ Di wilayah perkotaan, seperti di Yogyakarta, setidaknya anak usia sekolah dasar telah bermain game (di smartphone milik mereka) bisa lebih 3 sampai 4 jam setiap harinya. ${ }^{6}$ Hasil observasi peneliti, mereka sudah termasuk bagian dari kategori 'maniak' karena berlebihannya dalam menggunakan, baik dari frekuensi waktunya maupun intensitas penggunaannya.

Berdasarkan dua fenomena yang dijelaskan di atas tersebut, media sosial dan game saat ini sudah digunakan oleh segala tingkatan umur, tidak terkecuali anak-anak usia sekolah dasar. Tentu penggunaan media sosial dan game memiliki dua implikasi kuat di dalamnya, yakni positif dan negatif. Positifnya, dengan media sosial anak lebih memudahkan dalam belajar dan mengerjakan tugas sekolah. Sedangkan dengan bermain game, setidaknya anak lebih berpikir kreatif dan bisa meningkatkan kerja otak itu sendiri. Negatifnya, dengan media sosial, anak-anak mudah terjerumus dengan informasi yang menyesatkan dan bahkan mereka juga menonton sesuatu yang semestinya tidak mereka tonton. Dengan game, anak cenderung lebih memprioritaskan waktunya untuk bermain daripada kegiatan lain, seperti belajar dan berinteraksi dengan teman-temannya. Hal ini menjadi keprihatinan kita semua dan menjadi tantangan tersendiri oleh keluarga dan lembaga pendidikan untuk memberikan pendidikan yang baik dalam penggunaan media sosial dan game di kalangan anak.

Adapun dinamika penggunaan media sosial dan game yang dilakukan oleh kalangan anak-anak usia Madrasah Ibtidaiyah (Sekolah Dasar) di wilayah Yogyakarta pada beberapa tahun terakhir ini merupakan fenomena yang sangat

4 Lihat lebih detail di "Unity 2016 Mobile and VR Games Year in Review" pada http://images.response.unity3d.com/Web/Unity. Diakses pada Sabtu, 14 Juli 2018 pukul 22.00 WIB.

${ }^{5}$ Dony Canggah Guno, Gambar Perilaku Kecanduan Game Online pada Anak Usia Sekolah di Wilayah Kecamatan Magetan, Naskah Publikasi, Surakarta: UMS, 2018.

${ }^{6}$ Lihat juga Istikomariah, Pengaruh Intensitas Penggunaan Media Sosial terhadap Peer Acceptance Siswa kelas V Sekolah Dasar, Jurnal Basic Education, Vol. 5 Nomor 11, 2016. 
menarik untuk dilihat dan dikaji lebih jauh. Jika kita memahami hasil penelitian salah satu mahasiswa Universitas Negeri Yogyakarta, bahwa intensitas penggunaan media sosial di kalangan anak di salah satu Sekolah Dasar di Yogyakarta sangatlah tinggi. Hal tersebut dapat diamati melalui seberapa sering siswa Sekolah Dasar tersebut dalam melakukan update status, mengupload gambar, chatting serta aktivitas lainnya di media sosial. Dalam penelitian ini, peneliti melihat aktifitas anak-anak dengan media sosialnya melakukan update status 10 kali berturut-turut setiap harinya. Selain update status, anak-anak usia sekolah dasar ini juga sering menggunggah foto mereka di media sosial, Instagram. ${ }^{7}$ Ironisnya, ketika peneliti mengamati aktivitas siswa di media sosial (Blackberry Messenger), banyak siswa yang memanfaatkan fasilitas media sosial tersebut untuk saling ejek, saling menghina, dan melakukan bullying. Beberapa anak bahkan saling menghina satu sama lain yang semestinya tidak perlu dilakukan. ${ }^{8}$

Menurut Putri Ekasari dan Arya Hadi, setidaknya ada beberapa ciri-ciri dari pengguna internet yang termasuk kecanduan yaitu pengguna menghabiskan waktu lebih dari 40 jam per bulan. Hal itu berarti, dalam satu hari pengguna yang intensitas penggunaan internetnya tinggi akan mengakses internet lebih dari 1,3 jam. ${ }^{9}$ Dan intensitas penggunaan internet ini sudah terjadi di kalangan anak usia sekolah dasar di Yogyakarta, khususnya dalam penggunaan media sosial dan game. Tentu hal ini sangat menarik untuk dikaji, karena penggunaan media sosial lazim dipakai di kalangan remaja yang berusia 15-30 tahun, tetapi ini sudah dipakai di kalangan anak yang berusia 5-12 tahun. Bahkan penggunaan media sosial di kalangan anak-anak ini digunakan sesudah pulang sekolah, yang tentu memiliki waktu penggunaan sangat 'longgar' dibanding waktu belajar di sekolah.

${ }^{7}$ Istikomariah, Pengaruh Intensitas Penggunaan Media Sosial terhadap Peer Acceptance Siswa kelas V Sekolah Dasar, Jurnal, Yogyakarta: Universitas Negeri Yogyakarta, 2016.

${ }^{8}$ Ibid.

${ }^{9}$ Putri Ekasari dan Arya Hadi Dharmawan, Dampak Sosial Ekonomi Masuknya Pengaruh Internet dalam Kehidupan Remaja di Pedesaan, Jurnal Sosiologi Pedesaan Departemen Sains Komunikasi dan Pengembangan Masyarakat, Bogor: Fak.Ekologi Manusia IPB, 2012, hlm. 60. 
Begitu juga dengan permainan game yang semestinya dilakukan oleh remaja dengan kontrol waktu yang tepat, tetapi justru game ini dilakukan oleh anak-anak baik di warnet (warung internet), maupun di handphone mereka sendiri tanpa memperhitungkan durasi waktu penggunaan.

Kita bisa temui di sore maupun malam hari, keaktifan menggunakan media sosial dan game kalangan anak-anak di Yogyakarta semakin terlihat jelas. Bahkan di kasus tertentu, anak-anak rela menghabiskan uang jajannya untuk bermain game online di warnet dengan berinteraksi dengan temannya melalui media sosial Facebook, WhatsApp, Instagram dan lainnya. Dalam survei awal peneliti ke salah satu sekolah Madrasah Ibtidaiyah di Gunungkidul, didapatkan bahwa anak-anak MI yang telah menggunakan media sosial karena mereka ingin mengikuti zaman. ${ }^{10}$

Memahami hal tersebut di atas, menjadi menarik jika dinamika penggunaan media sosial, khususnya WhatsApp, Instagram, dan Facebook, dan penggunaan permainan game di kalangan anak-anak usia Sekolah Dasar (dalam hal ini siswa MI/Madrasah Ibtidaiyah) di Yogyakarta dikaji secara mendalam dengan pendekatan interdisipliner. Karena dengan pendekatan ini, fenomena atau dinamika menjadi objek kajian mampu ditelaah dan dianalisa dengan baik dari berbagai aspek kajian. Sehingga fenomena penggunaan media sosial di kalangan siswa MI ini dapat mengungkapkan hasil kajian secara utuh, menyeluruh dan komprehensif.

\section{B. METODE PENELITIAN}

Metode yang digunakan dalam penelitian ini adalah metode eksploratif. Dari metode ini, peneliti berusaha meneliti secara komprehensif sejauhmana pengaruh penggunaan media sosial dan game di kalangan anak Madrasah Ibtidaiyah di Yogyakarta. Data yang dimaksudkan dalam penelitian ini adalah dengan menggunakan pendekatan kuantitatif (quantitative research). Dalam

\footnotetext{
${ }^{10}$ Wawancara dengan siswa MI N 1 Bantul pada Senin, 16 April 2018 pukul 09.40 WIB.
} 
metode ini, peneliti menggunakan dua macam data, yaitu data primer dan data sekunder. Terkait dengan data primer, peneliti akan menyebarkan questioner kepada anak di dua Madrasah Ibtidaiyah di Yogyakarta, yakni di MI Ma'arif Sananul Ula Piyungan Bantul, dan MI Negeri 1 Bantul.

Peneliti juga memperkuat data primer tersebut dengan melakukan wawancara dengan peserta didik, guru, orangtua dan praktisi pendidikan. Karena dengan itu, peneliti terjun langsung di lokasi penelitian untuk melihat langsung aktifitas sehari-hari yang dilakukan oleh anak Madrasah Ibtidaiyah di Yogyakarta tersebut. Adapun teknik pengumpulan data adalah dengan menggunakan instrumen pengumpulan data berupa quesioner kepada responden. Quesioner disebarkan ke dua Madrasah Ibtidaiyah yang diisi oleh kelas 5 dan kelas 6 di masing-masing sekolah.

Untuk meningkatkan validitas dan reliabilitasnya, peneliti juga ikut kegiatan yang dilakukan anak-anak, seperti mengikuti kegiatan di sekolah. Sementara itu, terkait tentang data sekunder, peneliti akan memperkuat data-data yang ada dengan mengumpulkan buku-buku, koran, artikel, jurnal penelitian, filefile dokumentasi dari berbagai pihak, skripsi, tesis, disertasi dan bahan-bahan kepustakaan lain yang relevan.

\section{HASIL DAN PEMBAHASAN}

\section{a. Konsep Pendekatan Interdisipliner}

Pendekatan interdisipliner merupakan pendekatan yang memiliki tujuan dalam memecahkan suatu masalah dengan menggunakan telaah berbagai sudut pandang ilmu serumpun yang relevan secara terpadu. Yang dimaksud dengan ilmu serumpun dalam konteks ini adalah ilmu-ilmu yang berada dalam rumpun ilmu tertentu, yaitu rumpun Ilmu-Ilmu Kealaman (IIK), rumpun Ilmu Ilmu Sosial (IIS), atau rumpun Ilmu Ilmu Budaya (IIB) sebagai alternatif. Sedangkan ilmu 
yang relevan dalam hal ini adalah ilmu-ilmu yang cocok digunakan dalam pemecahan suatu masalah. ${ }^{11}$

Adapun istilah terpadu yaitu ilmu yang digunakan dalam pemecahan suatu masalah melalui pendekatan ini dapat terjalin satu dengan yang lain secara tersirat (implicit) merupakan suatu kebulatan atau kesatuan pembahasan yang termasuk dalam setiap sub-sub uraiannya jika pembahasan atau uraian itu terdiri atas subsub uraian tersendiri. Ciri pokok dari pendekatan indisipliner ini adalah inter (terpadu antarilmu dalam rumpun ilmu yang sama) atau terpadunya itu. ${ }^{12}$

Dalam pendekatan interdisipliner, penelitian ini akan memfokuskan pada ranah tiga kajian, yakni 1). Teori agama (khususnya tata cara penggunaan media sosial dalam Islam oleh fatwa MUI), 2). Teori Psikologi Media, dan 3). Teori Ekologi Media. Dari ketiga teori ini, maka objek penelitian akan lebih digali dan dieksplorasi secara utuh dengan menggunakan beberapa kajian teori tersebut.

Dalam pendekatan agama, dalam melihat fenomena penggunaan media sosial di kalangan anak Madrasah Ibtidaiyah ini penulis menggunakan pendekatan dari Fatwa MUI Nomor 24 Tahun 2017 tentang Hukum dan Pedoman Bermuamalah melalui Media Sosial. ${ }^{13}$ Maka dengan adanya hal ini, maka sangat menarik bagaimana anak-anak usia sekolah dasar (Madrasah Ibtidaiyah) menggunakan media sosial untuk tujuan-tujuan mereka.

Dalam teori lain, penulis juga akan menjelaskan penggunaan media sosial (WhatsApp, Instagram, dan Facebook) dan game di kalangan anak Madrasah Ibtidaiyah (MI) melalui teori Psikologi, lebih khusus dalam teori Psikologi Media. Dalam pendekatan uses of gratification, Elihu Katz menyatakan bahwa seseorang secara aktif telah mengkonsumsi dan menggunakan media dalam konteks untuk memenuhi kebutuhan dirinya. Lanjut Katz, maka setidaknya terdapat empat

\footnotetext{
${ }^{11}$ Setya Yuwana Sudikan, Pendekatan Interdisipliner, Multidisipliner, dan Transdisipliner dalam Studi Sastra, Jurnal Paramasastra Vol. 2 Nomor 1 2015, hlm. 4-5

12 Ibid

${ }^{13}$ Lihat Fatwa MUI No. 24 Tahun 2017 tentang Hukum dan Pedoman Bermuamalah Melalui Media Sosial.
} 
kebutuhan umum dari para konsumen media, yakni diversion, personal relationship, personal identity, dan surveillance. ${ }^{14}$ Dari keempat yang ditawarkan oleh Katz tersebut tentu akan semakin menarik jika teori itu ditarik lurus dalam konteks penggunaan media sosial dan game di kalangan anak usia sekolah dasar, khususnya di Yogyakarta.

Terakhir, untuk melihat secara komprehensif dari objek penelitian ini, penulis juga akan menggunakan Teori Ekologi Media tentang penggunaan media sosial dan game. Pengaruh dari teknologi media terhadap masyarakat adalah inti dari teori ini. ${ }^{15}$ Dari ketiga teori ini, penulis akan mencoba memahami dan menganalisa secara detail bagaimana efek penggunaan media sosial (WhatsApp, Instagram, dan Facebook) dan game di kalangan anak Madrasah Ibtidaiyah di Yogyakarta ini. Diharapkan dengan beberapa teori ini mampu memberikan gambaran secara utuh sebagai pijakan untuk membuat kebijakan dalam konteks pendidikan Islam di era millenial saat ini.

\section{b. Efek Penggunaan Media Sosial dan Game di Kalangan Anak MI}

Berdasarkan pengamatan dan penggalian informasi pada peserta didik di dua Madrasah Ibtidaiyah di Yogyakarta, setidaknya ada empat hal positif yang didapatkan dari penggunaan media sosial, di antaranya :

1. Dengan media sosial (khususnya WhatsApp dan Facebook), mayoritas dari mereka menerangkan bahwa media sosial yang digunakannya berfungsi sebagai alat berkomunikasi dengan teman sekolahnya tentang tugas sekolah. Media sosial, bagi mereka, adalah alat untuk mencari informasi tentang pendalaman pelajaran di sekolah;

2. Dengan media sosial dan game, dijadikan mereka sebagai tempat merileksasi diri dari kepenatan berpikir selama di sekolah. Menghilangkan stress akibat

14 Antoni, Riuhnya Persimpangan Itu: Profil dan Pemikiran Para Penggagas Kajian Ilmu Komunikasi, Solo: Tiga Serangkai, 2004, hlm. 91

${ }^{15}$ Lihat lebih lanjut pada Richard West, Lynn H. Turner. Introducing Communication Theory Analysis and Application, Boston: Mc Graw Hill, 2007, hlm.140-145 
banyaknya pelajaran dan tugas sekolah memungkinkan mereka bermain media sosial. Saling canda tawa di kolom komentar dengan temannya di media sosial tersebut menjadi 'obat mujarab' sementara;

3. Dengan media sosial dan game, anak-anak memiliki banyak teman di dunia maya. Dilihat dari hasil penelitian, $80 \%$ teman di media sosialnya bukan berasal dari sekolah yang sama. Hanya $20 \%$ temannya berasal dari satu sekolah;

4. Dengan media sosial, anak-anak memiliki kepercayaan lebih dari temannya yang tidak punya. Berdasarkan observasi dan wawancara dengan anak-anak kelas 6 MI Sananul UIa, mereka meyakini bahwa dengan memiliki media sosial (Facebook dan Instagram), mereka telah mengikuti zaman yang modern.

Tidak hanya hal positif yang ditampilkan dalam penelitian ini, banyak pula hal-hal negatif dalam pendidikan dan kehidupan anak sehari-hari jika mereka terus menggunakan media sosial dan game, antara lain:

1. Waktu belajar semakin berkurang. Hal ini jelas, banyak di antara anak-anak Madrasah Ibtidaiyah menggunakan media sosial dan game rata-rata 3-4 jam dalam sehari. Jika diakumulasi, lebih dari 25 jam dalam seminggu digunakan dalam bermain game dan mengakses media sosial. Mereka cenderung memainkan handphone pada saat sore dan malam hari. Padahal jika dilihat dari aktifitasnya, seharusnya sore dimanfaatkan untuk mengaji Al Qur'an dan malam hari digunakan untuk belajar pelajaran (mengerjakan tugas, dan seterusnya);

2. Konsentrasi anak terganggu. Media sosial telah memberikan kenyamanan tersendiri bagi penggunanya. Selama bermedia sosial dan main game, anakanak di sekolah cenderung kurang fokus dalam menerima pelajaran dari gurunya. Bahkan di beberapa kasus anak, mereka tidak memperhatikan pelajaran hanya karena di antara mereka terus membahas permainan game yang selalu dilakukannya di luar sekolah. Maka hasil penelitian menunjukkan 
interaksi mereka dengan teman-temannya 36\% membahas game, 23\% membahas pelajaran, dan $20 \%$ membahas tingkah laku teman lainnya;

3. Moralitas anak menjadi rendah. Menurut hasil penelitian, ditemukan anak yang memiliki media sosial $71 \%$ sudah memiliki rasa dengan lain jenis, bahkan 39\% sudah berpacaran. Hal ini menjadi ironis, karena usia mereka belum menginjak dewasa. Di lihat usia, mereka masih labil dalam berinteraksi sosial, sehingga melalui media sosial, mereka bisa mengakses apapun, termasuk gambargambar pornografi;

4. Lebih berani berinteraksi dengan siapapun, khususnya dengan lawan jenis. Hasil penelitian mengejutkan bahwa melalui media sosial, mereka cenderung lebih intens berkomunikasi dengan lawan jenis daripada sesama jenis. Sebanyak 60\% berinteraksi dengan lawan jenis melalui WhatsApp, 18\% berinteraksi dengan orangtua, $22 \%$ berinteraksi dengan sesama jenis.

\section{c. Peran Orangtua dan Pemerintah dalam Penyadaran}

Semua orang harus menyadari bahwa media sosial saat ini telah menjadi fenomenal yang 'digandrungi' semua lapisan masyarakat, tak terkecuali kalangan anak-anak. Sejak 2 tahun terakhir, pengguna internet melonjak tajam hingga mencapai lebih dari 80 juta pengguna. Menurut berbagai survey, pengguna internet berbalik arah dengan banyaknya menggunakan internet dengan Smartphone-nya dibandingkan di warung internet (warnet). ${ }^{16}$ Penggunaan internet di Smartphone ini justru menjadinya sebagai pisau bermata dua. Dalam artian manfaat yang diperolehnya berbanding lurus dengan ancaman bahaya yang ditimbulkannya.

Ada tiga fenomena yang dapat terlihat untuk dikaji pada titik ini, lebih-lebih kajian dalam konteks pendidikan anak di keluarga. Pertama, orangtua cenderung membebaskan anaknya dalam menggunakan media sosial atau orang tua tidak




menyadari bahwa penggunaan media sosial bagi anak dapat menimbulkan ancaman besar bagi si anak dan keluarganya. Kedua, mudahnya anak mengekspresikan diri dan terlihat eksis oleh semua kalangan melalui media sosial. Ketiga, sosialisasi positif dan negatif yang ditimbulkan media sosial dari pemerintah tampaknya kurang (bahkan tidak) efektif ke diri anak dan lingkungan secara umum.

Sinergi terbaik adalah sinergi yang di dalamnya tidak hanya orangtua, anak, dan civitas akademika sekolah, tetapi juga diperlukan sinergi dari pemerintah. Pemerintah sebagai pemegang kekuasaan dan kebijakan tertinggi harus juga memahami lebih dalam tentang fenomena media sosial yang dilakukan oleh anak usia Sekolah Dasar, khususnya pada anak Madrasah Ibtidaiyah. Yang pertama yang harus dilakukan oleh pemerintah adalah membuat kebijakan sistematis yang tidak hanya tertuju pada Dinas Pendidikan terkait, tetapi juga sampai pada level satuan pendidikan dan orangtua. Misalnya, kewajiban dinas pendidikan dan satuan pendidikan (sekolah) melakukan sosialisasi rutin setiap bulan dan mengkontrolnya pada beberapa bulan selanjutnya sebagai efek dari sosialisasi tersebut.

Melalui Menteri Komunikasi dan Informasi, pemerintah harus terus menggalakkan sosialisasi media kreatif yang tertuju pada individu pengguna sosial di kalangan anak. Media kreatif ini tidak hanya menampilkan sisi positif dan menarik minat bagi anak, tetapi juga menayangkan ancaman bahaya jika salah menggunakan media sosial. Pemerintah bisa meningkatkan kerjasama dengan berbagai pihak, baik cendekiawan, lembaga swadaya masyarakat, praktisi pendidikan, psikolog, dan seterusnya untuk merumuskan isi dan cara-cara terbaik mengkampanyekan budaya positif bermedia sosial di kalangan anak.

Ketiga, sudah saatnya pemerintah melalui Menteri Pendidikan dan Budaya membuat regulasi pendidikan berbasis teknologi bagi anak usia sekolah dasar. Sehingga setiap anak di setiap sekolah di seluruh Indonesia menyadari bahwa 
manfaat teknologi tidak hanya digunakan untuk bermedia sosial dan game semata, tetapi bisa digunakan sebagai ajang kreatifitas yang produktif bagi kehidupan anak ketika dewasa kelak, seperti pendidikan formal robotik, dan seterusnya. Dalam penelitian terlihat, sebanyak $98 \%$ responden anak kelas 5 dan 6 Madrasah Ibtidaiyah di Yogyakarta sudah bisa mengoperasikan smartphone. Dengan adanya regulasi tersebut, diharapkan setiap anak di Madrasah Ibtidaiyah atau sekolah dasar diajarkan bagaimana menggunakan teknologi dengan beralih dari konsumen media, menuju produsen media itu sendiri. Maka pendidikan teknologi menjadi sangat urgen di zaman milenial-digital saat ini.

\section{d. Solusi Menanggulangi 'Maniak' Media Sosial dan Game pada Anak MI}

Zaman sudah berubah, dulu media sosial hanya diminati dan dipakai oleh masyarakat dewasa, tetapi saat ini justru anak-anak usia sekolah dasar dapat mudah mengakses media dan aktif di media tersebut. Hal ini tentu perkembangan teknologi yang sangat pesat memudahkan semua dalam mengakses informasi dan sumber berita. Dengan adanya media sosial, banyak kalangan (lebih-lebih anakanak) merasakan ada dunia baru dalam dirinya. Dunia yang nyaman dan menyenangkan karena dengan hanya diam seseorang bisa mudah terhubung dengan siapapun di penjuru dunia. Hanya dengan menggeser jari ke layar smartphone-nya, semua dapat melakukan berbagai hal tanpa harus keluar rumah. Dalam artian, media saat ini telah membantu banyak hal dalam memudahkan manusia dalam beraktifitas, sehingga banyak kalangan kecanduan dalam bermedia.

Namun di sisi lain, bagi anak usia sekolah dasar (Madrasah Ibtidaiyah), aktivitas dunia maya dalam media sosial dan game sampai saat ini masih menimbulkan dampak buruk. Bahkan di beberapa kejadian, banyak korban yang diakibatkan oleh media sosial, baik korban pelecehan seksual anak, perkelahian, 
dan seterusnya. Jika dilihat dari realitas sosial, dampak yang terlihat adalah sikap asosial (terputus dari lingkungan sosial sekitarnya).

Berbagai penelitian (termasuk hasil penelitian di dua MI di Yogyakarta ini), dampak buruk penggunaan media sosial dan game bagi anak masih mendominasi. Maka terdapat beberapa hal yang bisa dijadikan solusi dalam menanggulangi ‘maniak' media sosial dan game bagi anak, di antaranya:

1. Menanamkan Pendidikan Agama sebagai Pendidikan Nilai

2. Mengintensifkan Komunikasi di Lingkungan Keluarga

3. Meminimalisir Waktu Bermain Smartphone

4. Memprioritaskan Anak

5. Memahamkan Bahaya jika Berlebihan Bermedia Sosial

6. Mencari Media Alternatif daripada Media Sosial

7. Beraktifitas dalam Kegiatan yang Lebih Produktif

\section{e. Media Sosial dan Game pada Anak MI dalam Pendekatan Interdisipliner}

Kajian tentang media sosial di kalangan anak Madrasah Ibtidaiyah di Yogyakarta pada dasarnya dapat ditelaah dari berbagai disiplin ilmu. Sudut pandang yang berbeda dalam menyikapi makna dan arti media sosial serta pihak yang memanfaatkannya, khususnya di kalangan anak-anak sangat menarik untuk dianalisis, karena setiap disiplin ilmu tentu mempunyai pendekatan yang berbedabeda. Penggunaan media sosial di kalangan anak Madrasah Ibtidaiyah ini dapat dianalisa dengan pendekatan Interdisipliner sebagaimana berikut:

\section{Pendekatan Normatif (Agama)}

Media sosial tentu tidak terelakkan bagi kehidupan manusia. Apalagi di zaman perkembangan teknologi yang kian canggih ini. Jika saat ini tak menggunakan media sosial, mungkin bisa kita ibaratkan "masak sayur tanpa garam", yakni kehidupan modern seseorang saat ini hampa jika mereka tidak memiliki atau menggunakan media sosial. Segala informasi dan peristiwa apapun bisa didapatkan lewat media sosial. Begitu juga tentang adanya isi hati, pikiran, 
juga pengakuan jati diri seseorang kepada dunia. Seakan sudah tidak ada lagi ruang privasi. Semua menjadi ruang publik. Hal ini yang menjadikan media sosial memiliki ‘tanggungjawab' dalam perilaku sosial di masyarakat, khususnya di kalangan anak-anak usia Madrasah Ibtidaiyah.

Lantas, dalam pendekatan Normatif, pandangan Islam memahami tentang fenomena media sosial yang beberapa tahun ini sangat massif di masyarakat dunia. Menurut Rasulullah SAW yang digambarkan dalam hadis bahwa terdapat di antara tanda-tanda dekatnya kiamat adalah dzuhurul qalam (tersebarnya pena/tulisan). ${ }^{17}$ Dzuhurul qalam ini bisa berlaku pada media sosialarena dengan media sosial, seseorang bisa menulis apapun yang ia pikirkan dan hasil tulisan bisa disebarkan ke orang lain melalui alat media sosial tersebut.

Jika dzuhurul qalam digunakan oleh seseorang yang belum memiliki pengetahuan ilmu yang mencukupi serta keimanan agamanya yang kurang kuat, maka hal tersebut bisa digunakan dalam hal-hal yang merusak, dan hal-hal negatif lainnya. Memahami hal tersebut di atas, penggunaan media sosial di kalangan anak Madrasah Ibtidaiyah jika dilihat dari ilmu agama, maka sebaiknya tidak dilakukan. Karena hal tersebut lebih banyak pengaruh negatifnya daripada positifnya.

Memahami hal tersebut di atas, penggunaan media sosial kalangan anak Madrasah Ibtidaiyah jika dilihat dari ilmu agama, maka sebaiknya tidak dilakukan. Karena hal tersebut lebih banyak pengaruh negatif daripada positifnya. Usia anak Madrasah Ibtidaiyah tentu belum mengetahui secara detail bagaimana tata cara interaksi sosial di dunia maya melalui media sosial. Hal ini terlihat di dalam diagram penelitian di bawah ini tentang alasan anak memiliki akun media sosial.

\footnotetext{
${ }^{17}$ Lihat Kitab Syarah Musnad Ahmad. Hadist tersebut diriwayatkan oleh Imam Ahmad.
} 
Diagram 1 Alasan Siswa MI Memiliki Akun Media Sosial

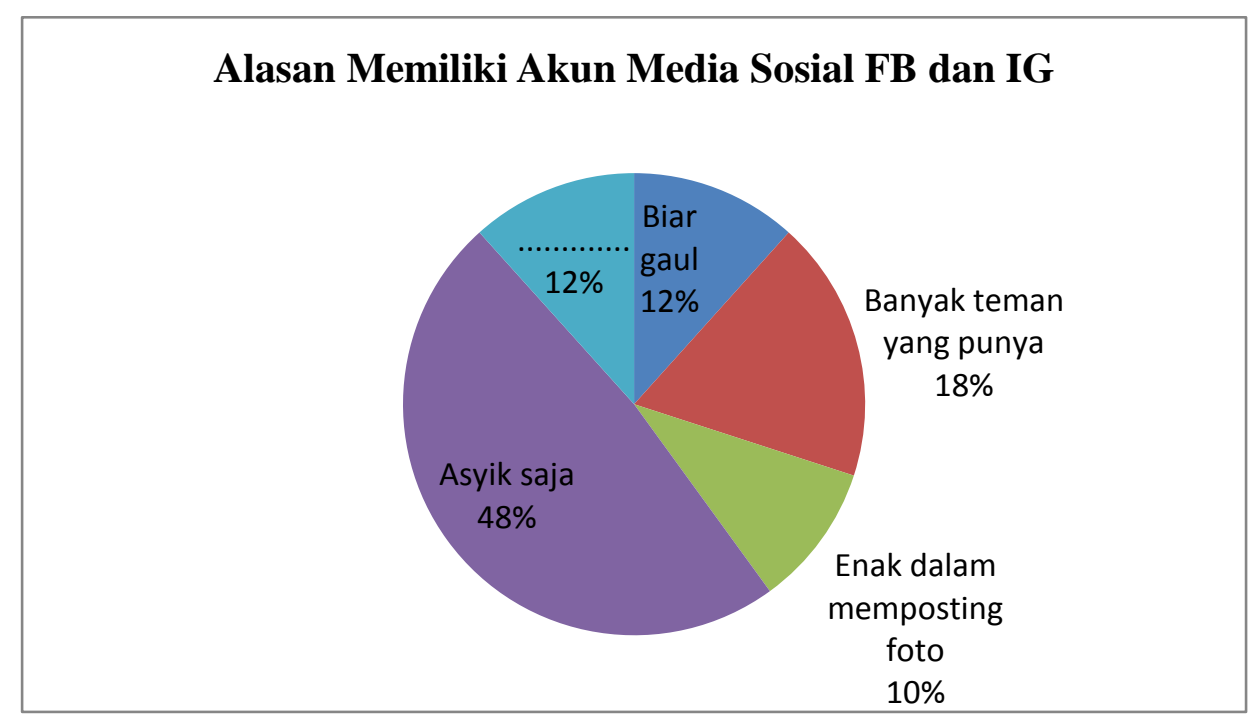

Berdasarkan diagram tersebut terlihat bahwa anak usia Madrasah Ibtidaiyah tentu belum memiliki alasan memiliki akun media sosial dan bagaimana cara yang baik menggunakannya dalam konteks agama. Tata cara penggunaan media sosial dalam konteks agama Islam adalah setiap muslim wajib mendasarkan pada keimanan dan ketakwaan, kebajikan (mu'asyarah bil ma'ruf), persaudaraan (ukhuwwah), saling wasiat akan kebenaran (al-haqq) serta mengajak pada kebaikan (al-amr bi al-ma'ruf) dan mencegah kemunkaran (alnahyu 'an al-munkar). Interaksi melalui media sosial hendaklah digunakan untuk mempererat ukhuwwah (persaudaraan).

Melihat tata cara menggunakan media sosial di atas, anak usia Madrasah Ibtidaiyah belum mempunya pemikiran ke arah sana. Justru penggunaan media sosial tersebut banyak digunakan hanya sebatas hiburan, kemaksiatan, saling 'ngrumpi' dengan teman-temannya dan hal-hal negatif lainnya (sebagaimana salah satunya yang terlihat dari diagram di atas). Maka dari itu, fungsi media sosial yang dilakukan anak usia Madrasah Ibtidaiyah tidak berimplikasi dalam ranah fungsi positif sebagai ladang ibadah (walaupun ada beberapa yang 
dijadikan menjadi hal positif), tetapi lebih banyak difungsikan ke arah hal-hal yang tidak perlu dan cenderung jauh dari tatanan ibadah seharusnya. Maka Hadist yang diriwayatkan oleh Bukhori yang mengatakan bahwa Nabi bersabda, "Jika urusan diserahkan bukan kepada ahlinya, maka tunggulah kehancuran itu. "18 akan berlaku dalam melihat fenomena ini.

\section{Pendekatan Psikologi Media}

Dalam pendekatan psikologi, penulis menganalisa penggunaan media sosial di kalangan anak usia Madrasah Ibtidaiyah ini dengan menggunakan Teori Psikologi Media. Teori ini mengungkapkan bahwa menurut George A. Miller, Psikologi Media adalah ilmu yang berusaha menguraikan, meramalkan dan mengendalikan peristiwa mental dan perilaku dalam komunikasi. Karena di beberapa tahun terakhir, media sudah menjadi 'senjata baru' bagi banyak bidang. ${ }^{19}$ Maka terdapat kebenaran bahwa menurut Elihu Katz, dalam Psikologi Media terdapat teori Peluru atau Jarum Hipodermik mengasumsikan bahwa media memiliki kekuatan yang sangat perkasa dan komunikan dianggap pasif atau tidak tahu apa-apa. Teori ini mengasumsikan bahwa semestinya seorang komunikator dapat menembakkan peluru komunikasi yang begitu ajaib kepada khalayak yang tidak berdaya (pasif).

Dalam konteks penggunaan media sosial di kalangan anak usia Madrasah Ibtidaiyah, sebagaimana peneliti meneliti di dua Madrasah Ibtidaiyah di Yogyakarta, seorang anak yang maniak terhadap media sosial biasanya memiliki kecenderungan berbeda dengan anak-anak lain seusianya. Ketika penulis berinteraksi dengan Irfan (siswa kelas 6), dia menceritakan bahwa sudah 2 tahun menggunakan media sosial Instagram dan Facebook. Dia beralasan, dengan

${ }^{18}$ Lihat Marzuqi Mustamar, Al Muqtatofat Li Ahlil Bidayat, Terj. Cet. 4, Yogyakarta: Naila Pustaka, 2017, hlm 184

19 Mulawarman, Aldila Dyas Nurfitri, Perilaku Pengguna Media Sosial Beserta Implikasinya Ditinjau dari Perspektif Psikologi Sosial Terapan, Jurnal Buletin Psikologi, Vol 25 Nomor 1 2017, hlm 36-37. 
menggunakan media sosial bisa memiliki banyak teman dari luar sekolahnya. Lebih lanjut, dia mengungkapkan bahwa dengan media sosial, dia lebih bahagia dan punya banyak angan-angan ketika di rumah. ${ }^{20}$

Memahami apa yang disampaikan Irfan dan dilihat dari diagram di atas, seusia anak MI biasanya berkembang dengan cara bermain-main dengan temantemannya di sekitar rumah selepas pulang sekolah. Menghabiskan waktu bercanda dengan teman sebayanya. Tetapi, jika sepulang sekolah mereka justru bermain media sosial, biasanya anak tersebut memiliki psikis interaksi sosial yang kurang baik.

Hal ini setidaknya dipengaruhi beberapa faktor. Salah satu penyebab anak usia sekolah dasar menggunakan media sosial adalah adanya ketidak harmonisan dalam keluarga, yakni adanya ketidak perhatian ke anak, pembiaran perilaku anak, memiliki hidup mewah dan tidak teratur, lemahnya interaksi sosial dengan tetangga sekitar dan kurangnya pengetahuan tentang bahaya media sosial buat anak.

Dalam realitas kehidupan, saat anak sibuk di luar rumah, yakni pagi berangkat ke sekolah, sore mengikuti les sampai menjelang waktu Maghrib, kemudian sampai di rumah harus belajar dan mempersiapkan semua untuk keesokan harinya. Aktifitas yang sangat melelahkan tersebut, maka smartphone menjadi teman 'terbaiknya' dalam mengobati kelelahan (baik kelelahan piker, maupun kelelahan fisik). Dengan itu, anak akan bermain games melalui smartphone dan berselancar melalui media sosial di dunia maya. Ketika anak sudah memegang smartphone, tentu ia akan sibuk dengan dunianya sendiri, tak ingin berinteraksi langsung dengan orang-orang di sekitarnya dan malas untuk melakukan hal lain. Di titik inilah yang semestinya menjadi perhatian serius bagi keluarga dan masyarakat secara umum.

\footnotetext{
${ }^{20}$ Wawancara dengan siswa MI Sananul Ula Piyungan Bantul pada Jum'at, 2 November 2018
} 
Dalam Psikologi Media juga dikenal dengan teori Bermain Psikologis. Teori ini menerapkan kerangka kerja yang lebih umum terhadap konsep hiburan media. Dalam teori Bermain Psikologis ini, media sosial (dalam hal ini WhatsApp, Instagram dan Facebook) dan game telah memiliki kekuatan yang luar biasa dalam mempengaruhi anak usia Madrasah Ibtidaiyah melalui hiburanhiburan di dalamnya. Fitur-fitur pelayanan (baik game dan hiburan lain) di media tersebut mampu diinjeksikan secara mendalam ke benak anak sehingga anak tidak berdaya dan pada akhirnya memiliki kecanduan akut pada media sosial yang dimilikinya.

Dengan ilmu psikologi media ini, menurut penulis (berdasarkan pada penelitian), kecanduan media sosial anak usia Madrasah Ibtidaiyah setidaknya berimbas pada diri anak. Adapun imbasnya tersebut antara lain:

a) Kemalasan belajar dan semangat menjalani hidup di dunia nyata;

b) Beresiko menimbulkan iri dan dengki antar teman;

c) Beresiko menimbulkan kecemasan dan ketidak stabilan emosional di diri anak;

d) Menghilangkan kejenuhan anak dengan menyendiri akibat beraktifitas belajar di sekolah;

e) Beresiko tinggi dalam menyebabkan anak yang individualistik.

Oleh karena itu, dengan analisa Interdisipliner secara baik, maka dapat ditemukan bahwa setiap individu yang bermasalah dapat diperbaiki kondisi psikisnya. Oleh karena itu, untuk mencegah dan lebih waspada terhadap pengaruh negatifnya media sosial anak usia sekolah, keharmonisan keluarga tentu harus ditingkatkan. Adanya perhatian dan kasih sayang terhadap anak merupakan kunci agar anak tidak terjerumus ke dalam 'maniak' media sosial.

Tidak hanya itu, saatnya terus memperhatikan lingkungan sekitar dan kurangi penggunaan smartphone dengan berinteraksi dengan orang lain. Perlu juga anak untuk dialihkan perhatiannya untuk mengisi waktu dengan hal-hal 
yang lebih bermanfaat, seperti ikut les (selesai pulang sekolah) dan ikut mengaji (di malam harinya), sehingga ia tidak menghabiskan waktunya berjam-jam dengan mengakses media sosial melalui smartphone pribadinya.

\section{Pendekatan Ekologi Media}

Dalam memahami ilmu sosiologi terkait fenomena penggunaan media sosial kalangan anak usia sekolah dasar, penulis menggunakan teori Ekologi Media. Menurut Mc.Luhan dalam West \& Turner, ekologi media mencoba melihat lingkungan media, gagasan tentang teknologi dan teknik, mode informasi dan kode komunikasi dapat memainkan peran penting dalam kehidupan manusia. Asumsi dari teori ekologi media antara lain:

a) Media mempengaruhi setiap perbuatan atau tindakan dalam masyarakat;

b) Media memperbaiki persepsi dan mengelola pengalaman;

c) Media mengikat dunia bersama-sama;

d) Media adalah pesan. ${ }^{21}$

Kehadiran teknologi memberikan pengaruh sangat besar dalam kehidupan manusia. Manusia memiliki hubungan simbolik dengan teknologi, di mana kita menciptakan teknologi dan kemudian teknologi kembali pada siapa diri kita. Adanya pergeseran struktur sosial masyarakat secara tidak langsung mengubah pola komunikasi yang terjadi di dalam masyarakat tersebut. Dalam konteks ini, media menjadi sumber dominan dalam memperoleh citra realitas sosial serta interpretasinya dan penilaiannya. ${ }^{22}$

Di kalangan anak Madrasah Ibtidaiyah di Yogyakarta (dalam teori Ekologi Media), usia anak saat ini sangat susah untuk lepas dari media. Media merupakan sebuah hal yang penting, bahkan menembus ke dalam kehidupan sehari-hari anak. Akhirnya keberadaan media memberikan pengaruh dalam kehidupan diri

${ }^{21}$ Abdul Karim Batubara, Media Ecology Theory, Jurnal Iqra'. Vol. 8 Nomor 2 Oktober 2014, hlm $134-135$

${ }^{22}$ Akhmad Zaini Abar, ke Arah Studi Etno Media, Jurnal Ilmu Sosial dan Ilmu Politik. Vol. 4 Nomor 4 November 2000, hlm 136. 
mereka dan lingkungannya. Untuk menganalisa hal ini, peneliti mencoba memberikan questioner di dua Madrasah Ibtidaiyah di Yogyakarta. Mereka mengungkapkan alasan penggunaan media sosial Instagram dimilikinya. Menurutnya, di samping untuk memperbanyak teman di luar sekolah, dengan menggunakan Instagram, mereka bisa terlihat gaul dan modern.

Memahami apa yang disampaikan mereka ini, terlihat pentingnya bagi mereka dalam menggunakan media sosial saat ini. Mereka merasa bahwa zaman harus mengubahnya seperti itu. Jika tidak mengikuti zaman, mereka merasa ditinggal 'zaman', yakni ditinggal teman dan lingkungan di sekitarnya.

Jika media sudah mempengaruhi masyarakat secara jauh, khususnya anakanak Madrasah Ibtidaiyah, maka kontrol sosial lingkungan tentu akan melemah. Hal ini diakibatkan setidaknya adanya dua faktor. Pertama, adanya budaya modern yang tidak bisa dibendung kembali, sehingga semua orang harus mengikuti budaya tersebut, termasuk anak-anak. Kedua, ketidak sadaran masyarakat tentang pengaruh media sosial terhadap perkembangan anak usia sekolah dasar. Sebagian masyarakat menganggap bahwa penggunaan media sosial oleh anak-anak adalah fenomena positif bagi anak, karena ilmu pengetahuan anak mampu berkembang seiring perkembangan zaman.

Ikatan media sangat 'ampuh' dalam merubah interaksi sosial anak Madrasah Ibtidaiyah, dalam artian lazimnya usia anak menggunakan interaksi sosial dengan bercengkerama dan bermain dengan teman sebayanya secara langsung, tetapi justru fungsi sosial tersebut berganti dengan alat mesin (smartphone, komputer, dan lainnya) sebagai teman dan tempat bermain.

Asumsi terakhir adalah media merupakan sebuah pesan. Pesan yang ditimbulkan oleh penggunaan media sosial dan game oleh anak Madrasah Ibtidaiyah adalah adanya pergeseran fungsi media ke dampak negatif dalam konteks interaksi dan komunikasi sosial bagi anak, sehingga perlu penanganan intensif, baik dari keluarga maupun lingkungan sekitar. Diperlukan penyadaran 
melalui sosialisasi tentang pengaruh media sosial bagi perkembangan usia anak, pengaruh negatif bagi kesehatan pikiran dan tubuh, dan pengaruh budaya modern yang kadang tidak cocok dengan budaya masyarakat. Sosialisasi dan penyuluhan ini memberi dampak positif bagi anak, keluarga dan lingkungan sehingga tatanan masyarakat yang nyaman, aman, kondusif dan penuh keharmonisan satu sama lain akan terjaga. Karena penggunaan media sosial bagi anak usia sekolah dasar bukan menjadi satu solusi dalam berinteraksi sosial, malah justru akan menjadi permasalahan baru dalam berinteraksi sosial di dunia maya dan dunia nyata. Salah satu permasalahan baru akibat dampak oleh media sosial adalah sebanyak 39\% dari 100 responden (anak kelas 5-6 MI) telah berpacaran dan mereka menggunakan media sosial untuk berinteraksi dengan pacarnya, sebagaimana terlihat di diagram di bawah ini:

Diagram 2 Komunikasi Anak MI dengan Pacarnya

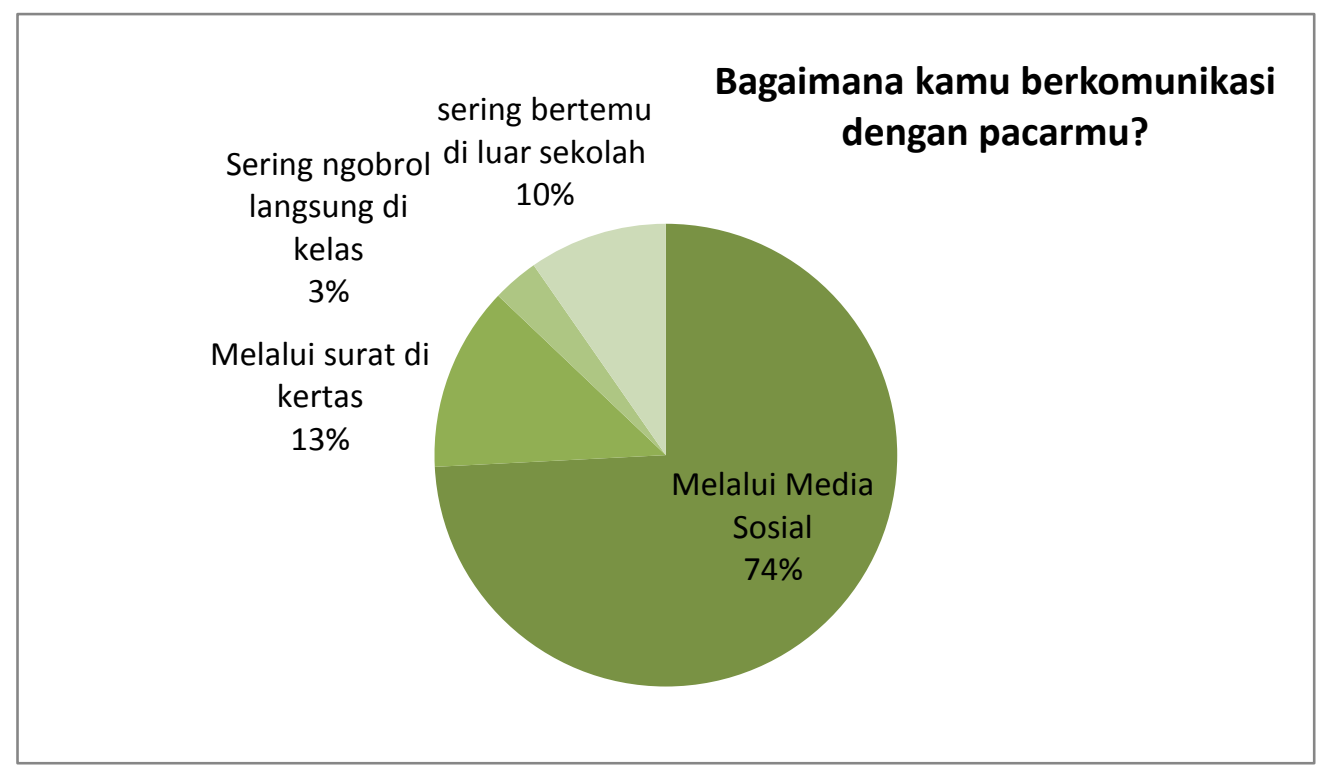

Diagram di atas tersebut memperlihatkan bahwa penggunaan media sosial pada anak usia sekolah dasar harus menjadi pengawasan penting, karena dalam sejarahnya, Yogyakarta merupakan kota pendidikan sekaligus kota yang menjunjung tinggi interaksi sosial satu sama lain. Masyarakat Yogyakarta 
merupakan masyarakat yang 'melek' segala macam bentuk modernitas, tetapi mereka tetap menyaring segala bentuk budaya yang merusak tatanan masyarakat. Maka dari itu, mereka sampai saat ini tidak lekang oleh waktu dengan terus memegang teguh nilai-nilai luhur dalam berinteraksi sosial dengan baik.

\section{SIMPULAN}

Media sosial dan game pada zaman milenial saat ini telah memperlihatkan bagaimana ia mampu memicu banyak perubahan manusia dalam bersosialisasi. Media sosial tak hanya berguna sebagai media interaksi semata, tetapi ia telah menjadi sumber informasi yang sangat cepat melebihi media-media lain. Ia tidak hanya memiliki dampak positif, tetapi juga memiliki banyak dampak negatif, khususnya bagi anak usia Sekolah Dasar (Madrasah Ibtidaiyah). Maka dari itu, solusi terbaik yang semestinya dilakukan adalah menyadarkan kembali masyarakat secara umum untuk bijaksana dalam bermedia sosial dan bermain game, khususnya penyadaran bagi anak usia Madrasah Ibtidaiyah. 


\section{DAFTAR PUSTAKA}

Abar, Akhmad Zaini, ke Arah Studi Etno Media, Jurnal Ilmu Sosial dan Ilmu Politik. Vol. 4 Nomor 4 November 2000.

Antoni, Riuhnya Persimpangan Itu: Profil dan Pemikiran Para Penggagas Kajian Ilmu Komunikasi, Solo: Tiga Serangkai, 2004.

Batubara, Abdul Karim, Media Ecology Theory, Jurnal Iqra'. Vol. 8 Nomor 2 Oktober 2014.

Ekasari, Putri dan Arya Hadi Dharmawan, Dampak Sosial Ekonomi Masuknya Pengaruh Internet dalam Kehidupan Remaja di Pedesaan, Jurnal Sosiologi Pedesaan Departemen Sains Komunikasi dan Pengembangan Masyarakat, Bogor: Fak.Ekologi Manusia IPB, 2012.

Guno, Dony Canggah, Gambar Perilaku Kecanduan Game Online pada Anak Usia Sekolah di Wilayah Kecamatan Magetan, Naskah Publikasi, Surakarta: UMS, 2018.

Istikomariah, Pengaruh Intensitas Penggunaan Media Sosial terhadap Peer Acceptance Siswa kelas V Sekolah Dasar, Jurnal Basic Education, Vol. 5 Nomor 11, 2016.

------ Kitab Syarah Musnad Ahmad. Hadist tersebut diriwayatkan oleh Imam Ahmad.

Mustamar, Marzuqi, Al Muqtatofat Li Ahlil Bidayat, Terj. Cet. 4, Yogyakarta: Naila Pustaka, 2017.

Morissan, dkk., Teori Komunikasi Massa, Bogor: Ghalia Indonesia, 2010.

Sari Melati, Mahasiswa Pengguna Media Sosial (Studi Tentang Fungsi Media Sosial Bagi Mahasiswa Fisip UR), Jurnal JOM Fisip Vol. 2 Nomor 2 Oktober 2015.

Mulawarman, Aldila Dyas Nurfitri, Perilaku Pengguna Media Sosial Beserta Implikasinya Ditinjau dari Perspektif Psikologi Sosial Terapan, Jurnal Buletin Psikologi, Vol 25 Nomor 1 Tahun 2017. 
Priyono, Henry, Anthony Giddens Suatu Pengantar, Jakarta: Perpustakaan Populer Gramedia, 2003.

Rizzo, A., John, B, Newman, B., Williams, J. et.al, Virtual Reality as A Tool for Delivering PTSD Exposure Therapy and Stress Resilience Training, TT: Military Behavioral Health, 2013.

Soekanto, Soerjono, Sosiologi: Suatu Pengantar, Jakarta: PT. Raja Grafindo Persada, 2009.

Sudikan, Setya Yuwana, Pendekatan Interdisipliner, Multidisipliner, dan Transdisipliner dalam Studi Sastra, Jurnal Paramasastra Vol. 2 Nomor 1 2015.

West, Richard, Lynn H. Turner. Introducing Communication Theory Analysis and Application, Boston: Mc Graw Hill, 2007.

West, Richard dan Turner, Lynn H., Pengantar Teori Komunikasi, Jakarta: Salemba Humanika, 2009.

Rahardjo, Mudjia, Studi Kasus dalam Penelitian Kualitatif: Konsep dan Prosedurnya. Jurnal 2007, http://repository.uin-malang.ac.id.

---- "Unity 2016 Mobile and VR Games Year in Review" pada http://images.response.unity3d.com/Web/Unity.

www.kompas.com. 